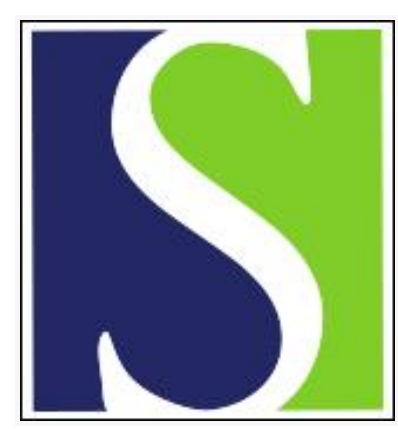

Scand J Work Environ Health 1991;17(6):441-443

https://doi.org/10.5271/sjweh.1682

Issue date: Dec 1991

Fever and respiratory symptoms after welding on painted steel.

by Sjogren B, Backstrom I, Fryk G, Jakobsson R, Milerad E, Plato N, Tornling $\mathrm{G}$

Affiliation: Department of Occupational Medicine, National Institute of Occupational Health, Solna, Sweden.

This article in PubMed: www.ncbi.nlm.nih.gov/pubmed/1788538

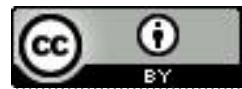




\title{
Fever and respiratory symptoms after welding on painted steel
}

\author{
by Bengt Sjögren, MD, ${ }^{1}$ Ivan Bäckström, MD, ${ }^{2}$ Gunnar Fryk, MSc, ${ }^{2}$ Robert Jakobsson, MSc, ${ }^{3}$ \\ Ewa Milerad, MD, ${ }^{3}$ Nils Plato, $\mathrm{MSc}^{3}{ }^{3}$ Göran Tornling, $\mathrm{MD}^{4}$
}

\begin{abstract}
SJÖGREN B, BÄCKSTRÖM I, FRYK G, JAKOBSSON R, MILERAD E, PLATO N, TORNLING G. Fever and respiratory symptoms after welding on painted steel. Scand J Work Environ Health 1991; 17:441-3. Electric-arc welding generates particles and gases that can induce chronic bronchitis and airway obstruction. In this case report two welders are described who had fever, spirometric deterioration, and bronchial hyperreactivity after welding steel painted with chloro-containing polymer lacquer. Pyrolysis of this paint releases many different compounds, for example, hydrogen chloride and complex chlorinated compounds.
\end{abstract}

Key terms: bronchial hyperreactivity, hydrogen chloride, paint.

Electric-arc welding generates particles and gases that can induce irritation of the airways and chronic bronchitis (1). Obstruction of the airways has been reported after the welding of stainless steel (2), epoxy-painted steel (3), and steel contaminated with unknown acid (4). Metal fume fever is not uncommon when zinccoated materials are welded (5), and a flulike illness has also been reported among welders exposed to ignited isocyanate-containing polyurethane foam (6).

In this case report we describe two welders who developed fever, spirometric deterioration, and bronchial hyperreactivity after welding steel painted with chlorocontaining polymer lacquer.

\section{Case 1}

The first welder, born in 1937, had worked as a mechanic in Finnish sawmills between 1955 and 1969. He moved to Sweden in 1969 , and since 1970 he has assembled truck platforms. This work involved welding approximately $4 \mathrm{~h} / \mathrm{d}$. He has always been a healthy nonsmoker and had never experienced any allergic symptoms. The paint on the assembled steel was changed to a two-component paint, Beckrysol Grundfarg BF $160^{\circledR}$, in the beginning of 1987.

In February 1987, after a day of intense metal inertgas welding of steel painted with the new paint, he experienced irritation of his eyes and throat and became dyspneic. He had a fever of $40^{\circ} \mathrm{C}$ on the same evening. $\mathrm{He}$ reexperienced these symptoms on five later occasions related to the welding of the painted steel. $\mathrm{He}$

1 Department of Occupational Medicine, National Institute of Occupational Health, Solna, Sweden.

2 Sigtunahälsan, Märsta, Sweden.

3 Department of Occupational Medicine, Karolinska Hospital, Stockholm, Sweden.

4 Department of Thoracic Medicine, Karolinska Hospital, Stockholm, Sweden.

Reprint requests to: Dr B Sjögren, Department of Occupational Medicine, National Institute of Occupational Health, S-171 84 Solna, Sweden. was on sick leave in March after the last episode of fever, and when reentering the workshop he experienced dyspnea when the same painted steel was welded.

Repeated spirometric measurements showed decreased volumes and flows that were slowly normalizing (table 1). His chest radiograph was normal two months after the first exposure. Provocation with histamine showed moderate hyperreactivity with a decrease in forced expiratory volume in $1 \mathrm{~s}\left(\mathrm{FEV}_{1.0}\right)$ of $21 \%$ at $4.0 \mathrm{mg} / \mathrm{ml}$ (reference value $20 \%$ decrease at $32 \mathrm{mg} / \mathrm{ml}$ ). His immunoglobulin E (IgE) was $100 \mathrm{units} / \mathrm{ml}$ (reference value $<120$ units $/ \mathrm{ml}$ ). His lung compliance and diffusion capacity was normal five months after the first event of exposure.

The spirometric deterioration has slowly normalized, but he still has symptoms from the airways and a reduced work capacity three years after the exposure.

\section{Case 2}

The second man, born in 1942, worked as a welder, plumber, and smith in his father's company between 1962 and 1980. Between 1980 and 1984 he worked as a mechanic without exposure to welding fumes. Since 1985 he has inspected manufactured truck platforms and dumpers. Each day he welded $25-40 \mathrm{~min}$ in order to improve inspected flaws. He stopped smoking in 1984 and had never had allergic symptoms.

At the end of October 1988 ne welded a $30-\mathrm{cm}$ long splice. The work was done after the workshift to avoid exposing all the work force to the acrid smell that emerged from the new paint, Realux Grund ${ }^{\circledR}$. Before welding he ground $4-5 \mathrm{~cm}$ around the splice, washed with xylene, and left the surface to dry for $30 \mathrm{~min}$. After the drying he welded for approximately $2 \mathrm{~min}$, and, while working, he smelled an acrid smell. In the night, $5-6 \mathrm{~h}$ later, he woke up with fever and dyspnea. He felt better after $15 \mathrm{~min}$ but remained weak for several hours. He continued his work although he felt tired 
Table 1. Change in the spirometric values of case 1 over a period of one year. The numbers within parentheses give the percentage of the expected value.

\begin{tabular}{|c|c|c|c|c|c|c|c|c|}
\hline \multirow[b]{2}{*}{ Vital capacity } & \multirow{2}{*}{ 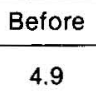 } & \multirow{2}{*}{$\frac{1 \text { month after }}{4.2}$} & \multirow{2}{*}{$\frac{1.5 \text { months }}{4.4}$} & \multirow{2}{*}{$\frac{4 \text { months }}{4.1}$} & \multirow{2}{*}{$\frac{5 \text { months }}{4.3}$} & \multirow{2}{*}{$\frac{9 \text { months }}{4.5}$} & \multicolumn{2}{|c|}{1 year } \\
\hline & & & & & & & 4.9 & $(97 \%)$ \\
\hline $\begin{array}{l}\text { Forced expiratory } \\
\text { volume in } 1 \mathrm{~s}\end{array}$ & 3.9 & 3.5 & 3.7 & 2.8 & 3.4 & 3.6 & 4.1 & $(102 \%)$ \\
\hline
\end{tabular}

Table 2. Change in the spirometric values of case 2 over a period of five months. The numbers within parentheses give the percentage of the expected value.

\begin{tabular}{lccrrrr}
\hline & Before & 2 weeks after & 1 month & 1.5 month & 5 months \\
\cline { 2 - 6 } Vital capacity & 5.7 & 4.3 & 4.3 & 4.8 & $(117 \%)$ \\
Forced expiratory volume in 1 s & 3.9 & 3.4 & 3.3 & 3.6 & $(97 \%)$ \\
\hline
\end{tabular}

and weak for several weeks. After this episode he experienced four similar events, although his symptoms were milder and shorter in duration.

Repeated spirometric measurements showed decreased volumes and flows that were slowly normalizing (table 2). The residual volume was high (158\% of the reference value) five months after the first exposure, but lung mechanics did not show any signs of emphysema. His chest radiograph was normal two weeks after his first exposure. Provocation with histamine showed hyperreactivity with a decrease in $\mathrm{FEV}_{1.0}$ of $31 \%$ at $1.0 \mathrm{mg} / \mathrm{ml}$ (reference value $20 \%$ decrease at $32 \mathrm{mg} / \mathrm{ml}$ ) six months after his first exposure. His IgE was 5 units $/ \mathrm{ml}$.

\section{Exposure}

These two welders were exposed to compounds generated from the pyrolytically decomposed paints Beckrysol BF $160^{\circledR}$ and Realux Grund ${ }^{\circledR}$. These two paints are epoxydized vegetable oils hardened by hexachloroendomethylenetetrahydrophthalic acid anhydride, also called HETacid anhydride. This type of paint has existed for about 10 years, and similar paints with other names are manufactured by other companies. These paints are used as rather thick coatings, $50-70 \mu \mathrm{m}$, in comparison with an ordinary finishing coat, which is about $20 \mu \mathrm{m}$ thick. The dried paint contains about $2 \%$ zinc, compared with about $15 \%$ zinc in a zinc chromate primer.

Beckrysol and Realux are chloro-containing polymer lacquers which are cured by a complex molecule containing chlorine. Heat decomposes these paints, and a wide range of compounds are formed, some of them chlorinated. To our knowledge there is no information on which pyrolytical products are formed, but hexachlorocyclopentadiene may be generated from HETacid (7). Other studies have shown that the pyrolysis products from chlorinated compounds are complex and vary with temperature. Welding creates a broad temperature curve around the splice. Therefore paint can decompose even if that around the splice has been removed.
Sampling with Dräger's glass ampuls from the emerging fume during the welding of steel painted with Beckrysol and Realux showed hydrogen chloride at levels above $100 \mathrm{ppm}$ but no phosgene. Hydrogen chloride was not detected when only steel was welded. The air concentration of zinc was not measured.

Both welders worked with the metal inert-gas welding technique. Fumes containing the decomposed paint reached the breathing zone, as it was difficult to use local exhaust ventilation. The workers had been exposed to several chlorinated compounds other than hydrogen chloride. The intensity of the exposure can vary considerably, depending on posture and work load. It is difficult to estimate the individual exposure of these men in qualitative and quantitative terms without a comprehensive reconstruction of the welding situation.

\section{Discussion}

These two welders had fever and long lasting, although reversible, spirometric deterioration after welding steel painted with chloro-containing polymer lacquers. The bronchial hyperreactivity and the spirometric results indicate an obstructive disease, but restrictive changes cannot be excluded. The overall picture indicates a toxic alveolitis or reactive airways dysfunction syndrome. Reactive airways dysfunction syndrome is characterized by asthma and bronchial hyperreactivity, which develops after one or repeated exposures to high levels of low-molecular irritants of the airways (8).

Hydrogen chloride is very irritant, and air concentrations between 50 and $100 \mathrm{ppm}$ are extremely irritating to the airways (9).

Zinc fumes may provoke zinc fume fever. It is, however, unlikely that exposure to zinc caused the fever, as the exposure to zinc was probably low.

Hexachlorocyclopentadiene is a compound which is possibly generated by pyrolytical decomposition. This chemical may cause airway irritation but probably not fever (10).

Exposure to trimellitic anhydride has induced a respiratory syndrome (11) that has some similarities 
to the symptoms of these two welders. Thus another anhydride, HETacid anhydride, possibly liberated during the welding of these paints, may play a role as a causative agent.

These observed adverse effects from the welding of steel painted with chloro-containing polymer lacquer have not been reported previously to our knowledge. Exposure to high levels of pyrolytically decomposed compounds can be seen when painted steel is welded. It is, however, impossible to pinpoint the compound or combination of compounds responsible for the described symptoms.

This report is a warning against the welding of steel painted with these paints, as the procedure causes a long-lasting disease. The Swedish National Board of Occupational Safety and Health recommends grinding to remove paints before welding (12). It is however uncertain whether or not even a $10-\mathrm{cm}$ zone around the splice is broad enough to protect the welder totally from the fumes and gases generated from the decomposition of this type of paint.

\section{References}

1. Sjögren B. Effects of gases and particles in welding and soldering. In: Zenz C, ed. Occupational medicine. 2nd edition. Chicago IL: Year Book Medical Publishers Inc, 1988:1053-60.

2. Keskinen H, Kalliomäki P-L, Alanko K. Occupational asthma due to stainless steel welding fumes. Clin Allergy $1980 ; 10: 151-9$.
3. Keskinen $\mathbf{H}$, Grenquist B. Astma orsakad av svetsning av epoximålat järn [Asthma caused by welding on epoxypainted iron]. In: Institutet för Arbetshygien i Finland. 30 Nordiska yrkeshygieniska mötet, Åbo $12-14$ oktober 1981. Helsinki: Institute of Occupational Health, 1981: 110.

4. Brooks SM, Weiss MA, Bernstein IL. Reactive airways dysfunction syndrome. J Occup Med 1985;27:473-6.

5. Ross DS. Welders' metal fume fever. J Soc Occup Med 1974;24:125-9.

6. Broughton A, Thrasher JD, Gard Z. Immunological evaluation of four arc welders exposed to fumes from ignited polyurethane foam: antibodies and immune profiles. Am J Ind Med 1988;13:463_72.

7. Keith L, Walters D. Compendium of safety data sheets for research and industrial chemicals: part I. Deerfield Beach, FL: VCH Publishers, 1985:306-7.

8. Tarlo SM, Broder I. Irritant-induced occupational asthma. Chest 1989;96:297-300.

9. Stokinger HE. The halogens and the nonmetals boron and silicon. In: Clayton GD, Clayton FE, ed. Patty's industrial hygiene and toxicology; vol 2B. New York, NY: John Wiley \& Sons, 1981:2959-61.

10. Morse DL, Kominsky JR, Wisseman CL, Landrigan PJ. Occupational exposure to hexachlorocyclopentadiene. JAMA 1979;241:2177-9.

11. Zeiss CR, Patterson R, Pruzansky JJ, Miller MM, Rosenberg M, Levitz D. Trimellitic anhydride-induced airways syndromes: clinical and immunological studies. J Allergy Clin Immunol 1977;60:96-103 .

12. Swedish National Board of Occupational Safety and Health. Smältsvetsning och termisk skärning [Welding and thermal cutting). Stockholm: Liber Distribution, 1989. (AFS 1989:1.)

Received for publication: 15 April 1991 